\title{
Intergenerational and Gender Differences in Sexual Life and Addictive Substance Use
}

\author{
Zrinka Puharić1,2, Rudolf Kiralj ${ }^{1}$, Filip Puharić ${ }^{3}$, Ana Zeko ${ }^{1}$, \\ Ana Žulec ${ }^{4}$ \\ ${ }^{1}$ University of Applied Sciences Bjelovar, Bjelovar, Croatia, ${ }^{2}$ Faculty of Dental Medicine \\ and Health, Osijek, Josip Juraj Strossmayer University of Osijek,Osijek, Croatia, ${ }^{3}$ Univer- \\ sity of Rijeka, Medical faculty, Rijeka, Croatia, ${ }^{4}$ Catholic University of Croatia, Zagreb, \\ Croatia
}

\begin{abstract}
Aim: Explore the habits of sexual life, knowledge, history and addictive substances use, analyze differences and similarities according to sex, age, religion, place of residence, parental education and generation. Methods: 364 random participants (17- 56 years), visiting the outpatient department of the General hospital Bjelovar from 1st of January to 1st of June 2017. We used two criteria to include a person in the study-non health education occupation and finished high school diploma degree minimum. All subjects gave informed consent. The self-designed anonymous questionnaire contained general socio-demographic questions and those related to sexual behavior and addictive substances use. Results: Significantly more men than women use addictive substances, addictive substances are more often used in urban areas, men are less knowledgeable about sexually transmitted diseases, women have older partners, men have partners of the same age or younger, the age of first sexual intercourse as well as the number of sexual partners and the consumption of addictive substances shifts to through generations to a lower age limit, level of parental education has no protective effect on the risky behavior of participans. Life in rural areas and religious practice can be indicated as a protective factor for risky behavior. Conclusion: The results put new challenges in front of the experts in the humanities and public health areas as they provide insight into the changing sociological phenomena through decades and describe the Croatian society between the phenomena of globalization and retradionalisation. This and similar research may encourage relevant measures of prevention of these trends.
\end{abstract}

Keywords: alcohol/tobacco/drug use, family life/sexuality, first sexual intercourse, knowledge, health education

Copyright @ 2020 KBCSM, Zagreb

e-mail: alcoholism.kbcsm@gmail.com•www.http://apr.kbcsm.hr

\section{Introduction}

\section{Correspondence to:}

Zrinka Puharić, Assistant Professor, MD, PhD

University of Applied Sciences Bjelovar

Trg E.Kvaternika 4, 43000 Bjelovar, Croatia

Phone:+ 38591 798-1653

E-mail: zpuharic@vub.hr
Global aging in developed countries indicated the question of demographic renewal and preservation of sexual and reproductive health as one of the key objectives of national policies. Each year more than 400 million 
adults are diagnosed with a sexually transmitted disease, while $60 \%$ of the affected are under 25 years of age [1]. The use of addictive substances leads to an increased risk of having early sexual relations, as well as sexual intercourse without adequate protection from unwanted pregnancy and sexually transmitted diseases [2,3].

Aims of the study is to investigate the habits of sexual life, knowledge, history and addictive substances use through generation, according to parental education, place of residence, sex, age and religious believes.

\section{Methods}

\section{Subjects}

We included 364 random participants aged between 17 and 56 years $(\mathrm{M}=24.2, \mathrm{SD}=$ 6.8 years), visiting the outpatient department of the General hospital Bjelovar from 1st of January to 1st of June 2017. We used two criteria to include a person: non health education occupation and finished high school diploma degree. All subjects signed informed consent and anonymity was guaranteed.

\section{Measures}

The self-designed anonymous questionnaire was constructed in Technical College Bjelovar, Study of nursing and several pilot studies were performed before the final version. It contained general socio-demographic questions and questions related to: sexual behavior and addictive substances use in everyday life and during sexual intercourse; the use of drugs (stimulants) during intercourse; the first sexual intercourse and the use of contraception; current contraception used; the most accurate sources of information on contraception; information on the abortion the respondents or respondents' partners had; the number of sexual partners and frequency of urologist/gynecologist visits.

Six knowledge items were directed in order to assess knowledge about sexuality: the ability to recognize sexually transmitted diseases as well as the most common diseases in this group; ways of infection; the existence of human papillomavirus (HPV) vaccine; the most effective method of contraception; and the number of women who die of cervical cancer in Croatia every year. The level of parental education has been done according to completed year of education. The variable of years per sexual partner was calculated by dividing the years of sexual life (the difference between the age of the respondent and the age of first sexual intercourse) with the number of sexual partners. The variable of the number of sexual partners per year is reciprocal to the previous one, except that a small correction was introduced to prevent the division by zero - years of sexual life have been increased by 0.5 . The respondent sample was divided into four age groups for all variables, except for the variable of the age of first drug use where the sample was divided into two groups (17 - 25 and 26 - 56 years).

\section{Statistical analyses}

The respondents is divided into four age groups: $17-25$ years $(\mathrm{M}=20.8$; $\mathrm{SD}=1.8)$, $26-30$ years $(\mathrm{M}=28.0 ; \mathrm{SD}=1.1), 31-35$ years $(\mathrm{M}=33.0, \mathrm{SD}=1.6)$ and $36-56$ years $(\mathrm{M}=41.2, \mathrm{SD}=5.5)$ and the differences between the groups with regard to variables were tested using a one-way ANOVA test for statistical significance of 0.05 . First we represent statistically significant differences with regard to parental education (Table 1), then with regard to place of residence (Table 2) and with regard to sex (Table 3). We made 
regression analysis of factors predicting sexual behavior (Table 4), dependent variables are number of sexual partners, age of frst sexual intercourse, number of children, years of sexual activity and number of sexual partners per year. Predictors are sex, age, place of residence, religiosity and complete level of parental education. Next we represent statistically significant differences with regard to religious beliefs and among addiction behaviors and knowledge.

Most of the categorical variables were taken directly from the survey results, while some were calculated. Statistically significant differences of 0.05 were tested with the chisquare test. A series of metric variables were taken directly from the survey, one metric variable was calculated (years of sex life), and the other variables were obtained by applying the appropriate scale to categorical variables or by counting the correct answers. The relationship between various metric variables was tested for statistically significant correlation at the statistical significance level of 0.05 chi-square test, correlation test and oneway ANOVA test were performed using the IBM SPSS Statistics for Windows 20.0 (IBM Corp.; Armonk, NY, 2012.).

\section{Results}

\section{Sample characterisation}

There were $136(37.4 \%)$ men, 227 (62.4 $\%)$ women and $1(0.3 \%)$ transgender person. There were 346 heterosexual persons (95.1\%), 17 bisexual (4.6\%) and 1 homosexual person $(0.3 \%)$. Half of them came from urban area $52.7 \%$ and $47.3 \%$ from the rural areas; $77.5 \%$ were believers, $9.6 \%$ were

Table 1. Differences according to parental education

\begin{tabular}{lcccccccc}
\hline Variable & $\begin{array}{c}\text { Elementary } \\
(\%)^{*}\end{array}$ & $\begin{array}{c}\text { Secondary } \\
(\%)^{* *}\end{array}$ & $\begin{array}{c}\text { Higher } \\
(\%)^{* *}\end{array}$ & $\mathrm{~N}$ & df & $\chi^{2}$ & $\mathrm{p}$ & $\varphi$ \\
\hline Smoking & & & & 364 & 4 & 14.120 & 0.007 & 0.197 \\
$\quad$ Yes & 2.75 & 18.41 & 9.62 & & & & & \\
$\quad$ Sometimes & 1.10 & 9.62 & 5.49 & & & & & \\
$\quad$ No & 3.30 & 40.93 & 8.79 & & & & & \\
\hline Alcohol use & & & & 364 & 4 & 11.447 & 0.022 & 0.177 \\
$\quad$ Yes & 0.27 & 10.71 & 5.22 & & & & & \\
$\quad$ Sometimes & 4.12 & 42.03 & 15.66 & & & & & \\
$\quad$ No & 2.75 & 16.21 & 3.02 & & & & & \\
Urologist/gynaecologist Visits & & & & 364 & 6 & 15.398 & 0.017 & 0.206 \\
$\quad$ Never & 0.82 & 24.18 & 9.89 & & & & & \\
$\quad$ Once in 2 yrs. or more & 1.92 & 9.07 & 4.67 & & & & & \\
Rarely & 3.85 & 27.47 & 6.04 & & & & & \\
$\quad$ Once a year & 0.55 & 8.24 & 3.30 & & & & & \\
$\quad$ Several times a year & & & & & & & & \\
\hline
\end{tabular}

*not-completed or completed elementary education as the highest level of parental educational attainment;

${ }^{* *}$ secondary education as the highest level of parental educational attainment; ***higher education as the highest level of parental educational attainment 
Table 2. Differences according to place of residence

\begin{tabular}{lccccccc}
\hline Variable & $\begin{array}{c}\text { Urban area } \\
(\%)\end{array}$ & $\begin{array}{c}\text { Rural area } \\
(\%)\end{array}$ & $\mathrm{N}$ & $\mathrm{df}$ & $\chi^{2}$ & $\mathrm{p}$ & $\varphi$ \\
\hline Drug abuse & & & 364 & 1 & 5.562 & 0.018 & 0.130 \\
$\quad$ Yes & 14.29 & 7.69 & & & & & \\
$\quad$ No & 38.46 & 39.56 & & & & & \\
\hline Respondent abortion or respondent's & & & 327 & 1 & 4.617 & 0.032 & 0.133 \\
partner abortion* & & & & & & & \\
$\quad$ Yes & 4.28 & 0.92 & & & & & \\
$\quad$ No & 49.85 & 44.95 & & & & & \\
\hline Knowledge: the most frequent & & & 364 & 4 & 12.549 & 0.014 & 0.186 \\
sexually transmitted disease & & & & & & & \\
$\quad$ HIV/AIDS & 11.81 & 17.31 & & & & & \\
Syphilis & 2.20 & 2.47 & & & & & \\
Clamidia infection & 9.34 & 6.87 & & & & & \\
$\quad$ HPV infection & 28.30 & 20.60 & & & & & \\
$\quad$ Gonorrhea & 1.10 & 0 & & & & & \\
\hline
\end{tabular}

* respondents who have not had sexual intercourse have been excluded from the analysis

atheists and $12.9 \%$ undecided. The secondary school grade average mark was 4.1 on a scale from 2 to 5 . Most of the participans have parents with secondary school education (mothers: $62.9 \%$, fathers: $70.1 \%$ ). Onethird $(32.4 \%)$ is in a stable relationship but not living with a partner, $30.8 \%$ are not in a relationship, $20.6 \%$ were married, $11.8 \%$ are in a a stable relationship and live with their partner, and the rest are divorced or are widows/widowers. $78.6 \%$ have no children, and $10.2 \%$ of them have not had sexual intercourse. $1.9 \%$ of the respondents have had a sexually transmitted disease.

\section{Differences according to parental education}

Table 1 shows that respondents who have at least one parent with college or university education smoke and drink more than respondents with parents whose highest level of educational attainment was elementary or secondary education. The same applies for urologist/gynecologist visits.

\section{Differences according to place of residence}

Table 2 shows that respondents who live in urban areas more often take drugs than people living in rural areas, and they or their partners have had an abortion more often. Respondents from rural areas more often chose "HIV/AIDS" as the most common sexually transmitted disease, and more rarely "HPV infection" and "gonorrhea" than espondents from the urban area.

\section{Differences according to sex}

Table 3 shows that men drink and take drugs more than women. For the first sexual intercourse men chose peers or younger partners. The women chose the older partners. For the first sexual intercourse with contra- 
Table 3. Differences according to sex

\begin{tabular}{|c|c|c|c|c|c|c|c|}
\hline Variable & $\begin{array}{c}\text { Male } \\
(\%)\end{array}$ & $\begin{array}{c}\text { Female } \\
(\%)\end{array}$ & $\mathrm{N}^{*}$ & df & $\chi^{2}$ & $\mathrm{p}$ & $\varphi$ \\
\hline Alcohol use & & & 363 & 2 & 37.208 & $<0.00001$ & 0.320 \\
\hline Yes & 11.57 & 4.68 & & & & & \\
\hline Sometimes & 20.94 & 41.05 & & & & & \\
\hline No & 4.96 & 16.80 & & & & & \\
\hline Drug abuse & & & 363 & 1 & 10.740 & 0.001 & 0.179 \\
\hline Yes & 11.85 & 10.19 & & & & & \\
\hline No & 25.62 & 52.34 & & & & & \\
\hline First intercourse & & & 363 & 1 & 5.659 & 0.017 & -0.134 \\
\hline Yes & 31.68 & 58.13 & & & & & \\
\hline No & 5.79 & 4.41 & & & & & \\
\hline Age of first sexual partner $* *$ & & & 326 & 2 & 40.528 & $<0.00001$ & 0.353 \\
\hline Same age partner & 23.93 & 27.61 & & & & & \\
\hline Older $\geq 3 \mathrm{y}$ & 8.90 & 37.12 & & & & & \\
\hline Younger $\geq 3 \mathrm{y}$ & 2.45 & 0 & & & & & \\
\hline Use of contraception during first & & & 204 & 1 & 5.274 & 0.022 & 0.183 \\
\hline intercourse $* * *$ & 34,80 & 59.31 & & & & & \\
\hline Condom & 0 & 5.88 & & & & & \\
\hline \multicolumn{8}{|l|}{ Contraceptive pills } \\
\hline Current contraceptive method* & & & 326 & 4 & 36.135 & $<0.0001$ & 0.333 \\
\hline Contraceptive pills & 1.53 & 17.18 & & & & & \\
\hline Condom & 20.86 & 19.63 & & & & & \\
\hline Interrupted intercourse & 3.99 & 7.36 & & & & & \\
\hline Natural birth control methods & 1.53 & 2.76 & & & & & \\
\hline Nothing & 7.36 & 17.79 & & & & & \\
\hline $\begin{array}{l}\text { Intercourse under the influence of } \\
\text { alcohol* }\end{array}$ & & & 326 & 1 & 21.484 & $<0.0001$ & 0.264 \\
\hline Yes & 16.26 & 13.50 & & & & & \\
\hline No & 19.02 & 51.23 & & & & & \\
\hline Intercourse under the influence of drugs* & & & 326 & 1 & 18.428 & $<0.0001$ & 0.251 \\
\hline Yes & 5.21 & 1.23 & & & & & \\
\hline No & 30.06 & 63.50 & & & & & \\
\hline Urologist/gynaecologist visits & & & 363 & 3 & 159.107 & $<0.00001$ & 0.662 \\
\hline Never & 27.27 & 7.44 & & & & & \\
\hline Once in 2 yrs. or more rarely & 6.34 & 9.37 & & & & & \\
\hline Once a year & 2.48 & 34.99 & & & & & \\
\hline Several times a year & 1.38 & 10.74 & & & & & \\
\hline $\begin{array}{l}\text { Knowledge: sexual contact as the } \\
\text { only means of infection with sexually } \\
\text { transmitted disease }\end{array}$ & & & 363 & 2 & 14.356 & 0.001 & 0.199 \\
\hline Yes & 19.28 & 40.50 & & & & & \\
\hline No & 11.29 & 18.18 & & & & & \\
\hline I don't know & 6.89 & 3.86 & & & & & \\
\hline
\end{tabular}


Table 3. (Continued)

\begin{tabular}{|c|c|c|c|c|c|c|c|}
\hline Variable & $\begin{array}{c}\text { Male } \\
(\%)\end{array}$ & $\begin{array}{c}\text { Female } \\
(\%)\end{array}$ & $\mathrm{N}^{*}$ & df & $\chi^{2}$ & $\mathrm{p}$ & $\varphi$ \\
\hline $\begin{array}{l}\text { Knowledge: the most frequent sexually } \\
\text { transmitted disease }\end{array}$ & & & 363 & 4 & 51.233 & $<0.00001$ & 0.376 \\
\hline HIV/AIDS & 17.36 & 11.85 & & & & & \\
\hline Syphilis & 3.03 & 1.65 & & & & & \\
\hline Clamidia infection & 4.68 & 11.57 & & & & & \\
\hline HPV infection & 11.29 & 37.47 & & & & & \\
\hline Gonorrhea & 1.10 & 0 & & & & & \\
\hline Knowledge: HPV vaccine & & & 363 & 1 & 63.958 & $<0.00001$ & 0.426 \\
\hline CORRECT: yes & $14.05 \%$ & 49.86 & & & & & \\
\hline INCORRECT: no, I don't know & $23.42 \%$ & 12.46 & & & & & \\
\hline Knowledge: HPV vaccine & & & 363 & 2 & 66.363 & $<0.00001$ & 0.428 \\
\hline Yes & 14.05 & 49.86 & & & & & \\
\hline No & 6.61 & 4.41 & & & & & \\
\hline I don't know & 16.80 & 8.26 & & & & & \\
\hline $\begin{array}{l}\text { Knowledge: most effective contraceptive } \\
\text { method }\end{array}$ & & & 363 & 1 & 19.603 & $<0.00001$ & 0.238 \\
\hline CORRECT: contraceptive pills & 8.26 & 28.65 & & & & & \\
\hline $\begin{array}{l}\text { INCORRECT:condom, interrupted } \\
\text { intercourse, intrauterine device, } \\
\text { diaphragm }\end{array}$ & 29.20 & 33.88 & & & & & \\
\hline $\begin{array}{l}\text { Knowledge: most effective contraceptive } \\
\text { method }\end{array}$ & & & 363 & 4 & 43.561 & $<0.00001$ & 0.346 \\
\hline Condom & 17.63 & 14.60 & & & & & \\
\hline Interrupted intercourse & 4.96 & 2.20 & & & & & \\
\hline Contraceptive pills & 8.26 & 28.65 & & & & & \\
\hline Intrauterine device & 5.51 & 15.70 & & & & & \\
\hline Diaphragm & 1.10 & 1.38 & & & & & \\
\hline
\end{tabular}

*transgender respondents were excluded from the analysis; $* *$ respondents who have not had sexual intercourse have been excluded from the analysis; *** respondents who have not used contraception during first intecourse have been excluded from the analysis)

ception men often report that was used condoms, while women more often report that they have been taken pills. Women more likely than men report not to use contraceptives during intercourse. Men more likely have sexual intercourse while intoxicated as well as drug use than women. Women are more concerned about reproductive health than men. As the most effective birth control methods, men responsed „condom" and "coituss interruptus", while women gave the answer "pill" and "spiral". 
Table 4. Regression analysis of factors predicting sexual behavior

\begin{tabular}{|c|c|c|c|c|c|c|c|}
\hline $\begin{array}{l}\text { Dependent } \\
\text { variable }\end{array}$ & Predictors & Beta & $\mathrm{P}$ & $\mathrm{R}$ & Adj. $\mathrm{R}^{2}$ & F ratio & df \\
\hline $\begin{array}{l}\text { Number } \\
\text { of sexual } \\
\text { partners }\end{array}$ & $\begin{array}{l}\text { female } \\
\text { rural } \\
\text { atheist } \\
\text { unspecified } \\
\text { unfinished elementary / } \\
\text { elementary } \\
\text { highschool } \\
17-25 \\
26-30 \\
31-35\end{array}$ & $\begin{array}{r}-0.317 \\
-0.026 \\
-0.015 \\
0.063 \\
0.044 \\
\\
0.125 \\
-0.067 \\
0.056 \\
0.076\end{array}$ & $\begin{array}{l}0.000 * * * \\
0.701 \\
0.824 \\
0.354 \\
0.563 \\
\\
0.091 \\
0.511 \\
0.527 \\
0.369\end{array}$ & 0.351 & 0.087 & $3.394 * * *$ & 9.226 \\
\hline $\begin{array}{l}\text { Age of } \\
\text { first sexual } \\
\text { intrecourse }\end{array}$ & $\begin{array}{l}\text { female } \\
\text { rural } \\
\text { atheist } \\
\text { unspecified } \\
\text { unfinished elementary / } \\
\text { elementary } \\
\text { highschool } \\
17-25 \\
26-30 \\
31-35\end{array}$ & $\begin{array}{r}0.096 \\
-0.138 \\
-0.013 \\
-0.112 \\
-0.065 \\
\\
-0.038 \\
-0.313 \\
-0.024 \\
-0.084 \\
\end{array}$ & $\begin{array}{l}0.158 \\
0.042^{*} \\
0.846 \\
0.102 \\
0.393 \\
\\
0.604 \\
0.002^{*} \\
0.789 \\
0.321 \\
\end{array}$ & 0.342 & 0.080 & $3.194 * 0 *$ & 9.226 \\
\hline $\begin{array}{l}\text { Number of } \\
\text { children }\end{array}$ & $\begin{array}{l}\text { female } \\
\text { rural } \\
\text { atheist } \\
\text { unspecified } \\
\text { unfinished elementary / } \\
\text { elementary } \\
\text { highschool } \\
17-25 \\
26-30 \\
31-35\end{array}$ & $\begin{array}{r}0.014 \\
0.015 \\
-0.045 \\
0.044 \\
0.228 \\
\\
0.073 \\
-0.973 \\
-0.475 \\
-0.212 \\
\end{array}$ & $\begin{array}{l}0.741 \\
0.726 \\
0.292 \\
0.311 \\
0.000^{* * *} \\
0.125 \\
0.000^{* * *} \\
0.000^{* * *} \\
0.000^{* * *} \\
\end{array}$ & 0.800 & 0.625 & $42.771 * * *$ & 9.226 \\
\hline $\begin{array}{l}\text { Years of } \\
\text { sexual activity }\end{array}$ & $\begin{array}{l}\text { female } \\
\text { rural } \\
\text { atheist } \\
\text { unspecified } \\
\text { unfinished elementary / } \\
\text { elementary } \\
\text { highschool } \\
17-25 \\
26-30 \\
31-35\end{array}$ & $\begin{array}{c}0.092 \\
0.099 \\
-0.02 \\
-0.025 \\
0.088 \\
\\
-0.049 \\
-0.940 \\
-0.399 \\
-0.304\end{array}$ & $\begin{array}{l}0.067 \\
0.048^{*} \\
0.687 \\
0.619 \\
0.115 \\
\\
0.374 \\
0.000^{* * *} \\
0.000^{* * *} \\
0.000^{* * *}\end{array}$ & 0.721 & 0.500 & $26.507^{* *}$ & 9.226 \\
\hline $\begin{array}{l}\text { Number } \\
\text { of sexual } \\
\text { partners per } \\
\text { year }\end{array}$ & $\begin{array}{l}\text { female } \\
\text { rural } \\
\text { atheist } \\
\text { unspecified } \\
\text { unfinished elementary / } \\
\text { elementary } \\
\text { highschool } \\
17-25 \\
26-30 \\
31-35\end{array}$ & $\begin{array}{r}-0.331 \\
-0.061 \\
-0.046 \\
0.007 \\
-0.018 \\
\\
0.062 \\
0.427 \\
0.091 \\
0.059\end{array}$ & $\begin{array}{l}0.000^{* * *} \\
0.314 \\
0.441 \\
0.909 \\
0.792 \\
\\
0.353 \\
0.000 * * * \\
0.251 \\
0.442\end{array}$ & 0.536 & 0.258 & $9.712^{* * *}$ & 9.226 \\
\hline
\end{tabular}

${ }^{*} \mathrm{p}<.05{ }^{* *} \mathrm{p}<.01 * * * \mathrm{p}<.001$ 
Regression analysis of factors predicting sexual behavior

Table 4 shows that there are statistically significant differences between the age groups with regard to the age of the first sexual intercourse $(F=10.0, p<0.0001)$ shifted from 18.7 to 17.0 years. However, there are no statistically significant differences between age groups with regard to the number of sexual partners $(F=1.0, p=0.408)$, and this number is constant ( 3 partners). The youngest age respondents group have 0.43 more sexual partners per year than the oldest group. Female respondents have less sexual partners than male (0.32). Respondents in rural area had first sexual intercourse 0.14 year later that in urban area $(\mathrm{p}<0.001)$.

This phenomenon can be explained by an increase in promiscuity among younger age groups. However, the average level of promiscuity - years per sexual partner - shows a very significant statistical difference between the groups $(F=70.1, p<0.00001)$, because the values drastically decline from 11.4 to 1.8 years per partner. What is presented here are probably two samples: the increase in promiscuity in younger age groups and their still short sex life. The other average measure of promiscuity - the number of sexual partners per year - also shows a similar trend due to the same causes: due to statistically significant differences $(F=16.4, p<0.0001)$, there is a clear increase in values from 0.1 to 0.8 per partner in favor of the youngest age group.

Fertility, expressed as the number of children, statistically significantly discriminates between the age groups $(F=149.2$, $p$ $<0.00001)$ : the average number of children per respondent declines drastically from 1.8 child in the oldest group to 0.1 in the youngest group, while the number of respondents who have children also declines (from 93.6\% to $4.5 \%$ ). Respondent with parents with unfinished elementary and elementary school have 0.23 more children that respondent wuth higher level of parental education. Older respondents entered later into sexual relationships than younger respondent, $(\mathrm{r}=$ 0.31, $\mathrm{p}<0.00001, \mathrm{M}=17.2, \mathrm{SD}=1.9$ years $)$. Participants with a higher number of previous sexual partners engage earlier in sexual relationships and have more partners $(\mathrm{M}=$ 2.9, $\mathrm{SD}=2.2$ ).

Statistically significant differences with regard to religious beliefs and addiction behavior and knowledge

Atheists smoke more and are more likely to consume drugs and alcohol than believers. A certain differentiation of groups exists in a one-way ANOVA test with regard to the number of sexual partners, but not at conventional level of statistical significance: the believers - 2.48 (1.71), the atheists -3.00 (2.36) and the undecided - 3.18 (2.57) of sexual partners, $\mathrm{df}=2, \mathrm{~F}=1.45, \mathrm{p}=0.237$.

Differentiation is more noticeable with regard to the age of the first intercourse: believers - 17.34 (1.91), atheists - 16.68 (1.83) and the undecided - 17.11 (1.53) years, df = $2, \mathrm{~F}=1.89, \mathrm{p}=0.153$. The indirect ascendant of religious beliefs on the differences between the sexes with regard to the age of the first sexual intercourse is statistically significant in one-way ANOVA test (equal variances of the two groups): men - 16.64 (1.83) and women - $17.58(1.80)$ years, $d f=1, \mathrm{~F}=$ $19.973, p<0.0001$. The same was confirmed by the t-test: $d f=324, \mathrm{t}=-4.47, p<0.0001$.

Respondents who start smoking early also start consuming alcohol $(\mathrm{r}=0.46, \mathrm{p}<$ $0.00001)$, enter sexual relationships ( $\mathrm{r}=0.33$, $\mathrm{p}<0.00001)$ and start using drugs at an ear- 
lier age $(\mathrm{r}=0.45, \mathrm{p}<0.00001)$. Respondents who started drinking at an earlier age also entered sexual relationships at an earlier age $(r$ $=0.31, p<0.00001)$, and earlier use of drugs also signifies earlier sexual relationships $(r=$ $0.33, p=0.01)$.

Respondents demonstrated average knowledge about sexuality (56.6 \% of respondents), significantly less respondents have below average knowledge (17.6 \% of respondents) and and above-average knowledge (22.8\% of respondents). The average number of correct answers was 3.6 / 7. Almost all generations are represented in the average knowledge. The youngest generations are fully differentiated, from no and poor knowledge, to average and above-average knowledge to complete knowledge.

Use of addictive substances shows that all generations are represented when it comes to complete abstinence, there was almost no usage of any addictive substance in older generations, middle and younger generation use up to two addictive substances, and younger generations use up to three types of addictive substances. The middle generation abstains from all addictive substances during sexual intercourse, and one, two or three types of substances are used by all generations, with the oldest generation slightly represented for the use of two or three substances.

\section{Discussion}

In Croatia, young people have their first intercourse at 17.5 years, while $9.7 \%$ of girls and $23.2 \%$ of boys have their first intercourse before the age of 16 [4]. A national survey on addictive substances use in the general population of Croatia shows that $35.4 \%$ of respondents use tobacco daily, men more frequent than women $37.7 \%$ vs. $33.0 \%$ ), and there is no differences between urban and rural area. Most of the respondents stated that they first smoked tobacco between the ages of 16 and 16.6 [5]. Throughout the entire sample (age 15 - 64), $86.3 \%$ of the respondents stated that they consumed alcohol, men $(89.0 \%)$ more frequent than women $(83.6 \%)$. A difference in life prevalence of alcohol consumption between urban and rural area was not found. The largest proportion of respondents stated that they consumed alcohol for the first time is between the ages of 25 and 34 [5].

The life prevalence of using drugs is more frequent in $25-34$ ages $(33.1 \%)$ and $15-24$ ages $(32.1 \%)$ groups, more than twice in man than in women $(27.1 \%$ vs. $13.5 \%)$, the highest among the respondents from big cities $(27.4 \%)$. The highest prevalence of taking any illegal drug in the last year was found in the youngest group of respondents $(20.4 \%)$, followed by the age group between the ages of 25 and $34(13.7 \%)$ [5]. Croatian population is mostly Catholic $86.3 \%$ [6], and research show that true believers are less determined to use addictive substances or have premarital sex, especially women $[7,8]$. Men in Croatia and Europe are more prone to risky behavior than women, which reduces their life expectancy $[9,10]$ and called "masculine norms" of behavior and "self-assertion of masculinity", which includes different types of health risks. It is therefore a public health problem in European countries which, according to the World Health Organisation guidelines, should be prevented by introducing adequate measures [10]. Some studies show an increased incidence of addictive substance abuse in adolescents of lower socioeconomic status who have been observed through a period of eight years [11], and ado- 
lescent girls living in urban areas, while the incidence for adolescents is constant [12].

Men have less knowledge about sexually transmitted disease than women in this and in similar studies [13,14]. Most adolescents had their first sexual intercourse at the age of 16 , most girls with older partners $(63 \%)$ [15]. Previous research reported that men have their first sexual intercourse at the age of 17.1 and women at the age of 16.5 years, both with older partners [16]. The average age of first sexual intercourse for a whole group of respondents was 17.3 years while in a similar survey on a sample of general population of Eastern Croatia (range 18 - 52 years, $\mathrm{M}=31.3, \mathrm{SD}=8.4$ years) the age was 17.7 years [17]. The age of first sexual intercourse and the number of sexual partners shifts through generations to a lower age limit like in similar research [18]. The trend of early sexual relations is still losing momentum, so that in the last two decades there is clearer stabilization of the age of the first sexual intercourse, the number of sexual partners and the prevalence of condom use [19]. These facts about the time dependent trends and their stabilization indicate a need for the entire Croatian society to adapt to new circumstances through adequate education and new attitudes toward sexuality.

Parental education has no protective effect on the risky behavior of children because adolescents more inclined to risky behavior have parents with higher level of educational attainment, and a similar thing can be observed between addictive substances use and a higher level of parental education [20]. In this research, we found that life in rural areas can be indicated as a protective factor for risky behavior like some other research [21].

Religiosity has a significant impact on attitudes toward sexuality and marriage in the
Republic of Croatia, whether general, or student population is concerned [22,23]. Research shows that the more religious individuals come first sexual intercourse later and at a younger age have less number of sexual partners [8,24]. For a deeper understanding of contemporary sexuality in Croatia what needs to be condsidered is the fact that Croatia, as well as other so-called post-communist transition countries, are undegoing processes between globalization and specific retraditionalization. In such societies, the struggle for women's rights and roles of women is slowly subsiding at the expense of ever increasing social requirements for the traditional role of women in patriarchal terms, the third child, reproductive role and the new ideal of a woman (fertility, motherhood, no abortion) [25]. In this regard, various social stakeholders are important - the government, families, individuals, non-governmental organizations and the church, all of which participate in the creation of public reproductive policies justifying them by wanting to improve the demographic situation, which in the case of Croatia leads to the formation of polarized pro-life blocks (traditionalists), pro-choice (liberal) and neutral blocks (moderate, situationist) [26]. It is therefore easy to understand that almost every statistically large sample of respondents will reflect this social division of Croatia with regard to attitudes about sexuality and sexual habits, and especially the role of women in society.

Strenght and Limitations of the study: The respondents' sample has a specific age structure so it can be used to detect a range of phenomena that comprise much of the general population in Croatia and also provides a variety of information on the time-varying variables. Limitation is relativelly small num- 
bers of participans and all participans were from same county.

Recommendations: for the practise (put an extra effort of health and educational workers in preventive measures with youth), for the future research (include higher number of participans from different parts of the Croatia).

\section{Conclusion}

The results is similar like some previous researches, but also make further research and analysis possible and put new challenges before the experts in the humanities and public health areas as they provide insight

\section{References}

1. Dehne KL, Riedner G. Sexually transmitted infections among adolescents the need for adequate health services. [Internet] 2005. [cited Dec 28 ${ }^{\text {th }}$ 2019]. Available from https://apps.who.int/iris/ bitstream/handle/10665/43221/9241562889.pdf ;jsessionid=71584B649DCC5A9F5E306D1E99E 647E6?seque.

2. Farid ND, Rus SC, Dahlui M, Al-Sadat N, Che' Rus S. Determinants of sexual intercourse initiation among incarcerated adolescents: a mixed-method study. Sigapore Med J. 2013;54:695-01.

3. Lee Sy, Lee HJ, Kim TK, Lee SG, Park EC. Sexually transmitted infections and first sexual intercourse age in adolescents: The nationwide retrospective cross-sectional study. J Sex Med. 2015;12:2313-23.

4. Kuzman M, Pavić-Šimetin I, Pejnović-Franelić I. Early Sexual Intercourse and Risk Factors in Croatian Adolescents. Coll Antropol. 2007;51:121-30.

5. Glavak Tkalić R, Miletić GM, Maričić J, Wertag A. Substance Abuse among the General Population in the Republic of Croatia: Research Report. Zagreb, Croatia: Institute of Social Sciences Ivo Pilar into the changing sociological phenomena through decades and appropriately describe the Croatian society between the phenomena of globalization and retradiconalisation. Since for each country it is important to have a healthy and work-efficient population and positive natural increase, this and similar research may encourage relevant state measures of prevention of these trends.

\section{Acknowledgements}

None.

\section{Conflicts of interest}

None to declare and Government of the Republic of Croatia - Office for Combating Drug Abuse; 2012.

6. Croatian Bureau of Statistics. Census of Population, Households and Dwellings 2011, Population by Citizenship, Ethnicity, Religion and Mother Tongue. Zagreb: Croatian Bureau of Statistics; 2013.

7. Schmitt DP. Personality, attachment and sexuality relating to dating relationship outcomes: Contrasting three perspectives on personal attribute interaction. Br J Soc Psychol. 2002;41:589-610.

8. Hardy SA, Raffaelli M. Adolescent religiosity and sexuality: An investigation of reciprocal influences. J Adolesc. 2003;26:731-9.

9. Ricijaš N, Krajcer M, Bouillet D. Rizična ponašanja Zagrebačkih srednjoškolaca-razlike s obzirom na spol. Odgojne znanosti. 2010;12:45-63.

10. Baker P, Dworkin SL, Tong S, Banks I, Shand T, Yamey G. The men's health gap: men must be included in the global health equity agenda. Bull World Health Organ. 2014;92:618-20.

11. Pitel L, Madarasova Geckova A, Rejineveld AS, Van Dijk JP. Socioeconomic gradient shifts in health-related behaviour among Slovak adoles- 
cents between 1998 and 2006. Int J Public Health. 2013;58:171-6.

12. Pitel L, Madarasova Geckova A, Reijneveld SA, Van Dijk JP. Degree of urbanization and gender differences in substance use among Slovak adolescents. Int J Public Health. 2011;56:645-51.

13. Sesar K, Šimić N, Bubalo P, Jurić S, Sesar D. Spolno ponašanje i znanje o spolno prenosivim bolestima učenika srednjih škola sa područja zapadnohercegovačke županije. Pedijatrija danas. 2010;6:53-65.

14. Bračulj A. Rizično seksualno ponašanje adolescenata na području grada Zagreba. Zagreb, Croatia: University of Zagreb, Faculty of EducationRehabilitation Sciences; 2015.

15. Dabo J, Malatestinić Đ, Janković S, Bolf-Malović M, Kosanović V. Reproductive health care of adolescents-models of prevention. Medicina. 2008;44:72-9.

16. Symons K, Vermeersch H, Van Houte M. The emotional experiences of early first intercourse-a multimethod study. J Adol Res. 2014;29:1-28.

17. Miškulin M, Miškulin I, Puntarić D, Mujkić A, Milas J, Bošnjak N. The characteristics of sexual behavior and extent of condom usage among sexually active Croatians from Eastern Croatia. J Turk Ger Gynecol Assoc. 2009;10:142-47.

18. Wellings K, Nanchahal K, Macdowall W, McManus S, Erens B, Mercer CH, et al. Sexual behavior in Britain: early heterosexual experience. Lancet. 2001;358:1843-50.

19. Kuzman M, Pejnović Franelić I. Adolescents' substance abuse experimentation. Paed Cro. 2010;54:94-101.

20. Landripet I, Šević S, Car D, Baćak V, Mamula M, Stulhofer A. Changing Sexuality? Results from the University of Zagreb First-Year Students Studies 1998-2008. Druš istraž. 2010;19:995-1014.

21. Son DT, Oh J, Heo J, Huy NV, Van Minh H, Choi $\mathrm{S}$, et al. Early sexual initiation and multiple sexual partners among Vietnamese women: analysis from the Multiple Indicator Cluster Survey, 2011. Glob Health Action. 2016;9:29575.

22. Marinović Jerolimov D, Ančić B. Religiosity and attitudes towards sexuality and marriage of adult population in Croatia. Druš istraž. 2014;23:111-32.

23. Bartolac A. Students' attitudes towards cohabitation and marriage. Soc Eko. 2013;22:107-31.

24. Mahoney ER. Religiosity and sexual behaviors among heterosexual college students. The J Sex Res. 1980;16:97-113.

25. Mićunović N. Gendered aspects of social change. Filozofija i društvo. 2006;17:191-7.

26. Milanović N. Constitutional elements of reproductive politics in Eastern Europe and Serbia. Etnološko-antropološke sveske. 2013;22:27-40.

\section{Međugeneracijske i spolne razlike u seksualnom životu i upotrebi sredstava ovisnosti}

Sažetak:- Cilj: Istražiti navike seksualnog života, znanje, povijest i uporabu sredstava ovisnosti, analizirati razlike i sličnosti prema spolu, dobi, religiji, mjestu prebivališta, roditeljskom obrazovanju i generaciji. Metode: 364 randomizirana sudionika (u dobi između 17-56 godina), ambulantni pacijenti Opće bolnice Bjelovar od 1 sijećnja do 1 lipnja 2017. Koristili smo dva kriterija za uključenje osoba u studiju: ne medicinsku okupaciju i završeno srednje školsko obrazovanje kao minimalni stupanj obrazovanja. Svi sudionici su dali informirani pristanak. Samoispunjavajući anonimni upitnik je sadržavao opća socio-demografska pitanja i ona povezana sa seksualnim ponašanjem i korištenjem sredstava ovisnosti. Rezultati: Značajno je više muškaraca nego žena koristilo sredstva ovisnosti, te su ta sredstva više korištena u urbanim sredinama, muškarci imaju manje znanje o spolno prenosivim bolestima, žene imaju starije partnere, muškarci imaju partnerice iste dobi ili mlađe. Dob prvog spolnog odnosa, kao i broj seksualnih partnera i konzumiranje sredstava ovisnosti prelazi s gener- 
acija na nižu dobnu granicu, razina roditeljskog obrazovanja nema zaštitni učinak na rizično ponašanje sudionika. Zaključak: Rezultati postavljaju nove izazove pred stručnjake za humanističke znanosti i javno zdravstvo, jer pružaju uvid u promjenjive sociološke pojave kroz desetljeća i opisuju hrvatsko društvo između pojava globalizacije i retradionalizacije. Ova i slična istraživanja mogu potaknuti odgovarajuće mjere prevencija ovih trendova.

Ključne riječi: alkohol/duhan/droga, obiteljski život/seksualnost, prvi seksualni odnos, znanje, zdravstvena edukacija 
